\title{
Islamic Education Curriculum of Ban Budhee School from The South Thailand Muslim Minority
}

\author{
Rohmatun Lukluk Isnaini \\ UIN Sunan Kalijaga Yogyakarta \\ lukluk isnaini@yahoo.com
}

\begin{tabular}{|c||c||c||}
\hline $\begin{array}{c}\text { Accepted: } \\
\text { Feb 10 } 10^{\text {th }} 2020\end{array}$ & Reviewed: & Published: \\
April 5 $5^{\text {th }}, 2020$ & May,30 3020 \\
\hline
\end{tabular}

\begin{abstract}
The Pattani area of Southern Thailand, precisely in the district of Laem Pho, there is a large school called Ban Budhee. It is a royal Islamic-based school that has applied Islamic education curriculum. This study aims to see the components of the curriculum in terms of the limitations of Muslim minority communities in their country in implementing the Islamic education curriculum. This research uses qualitative approach; researcher conducts in-depth interviews, field observation and documentation at the location. This paper focuses on the model of Islamic education curriculum in Muslim minority areas, especially in Ban Budhee School. The Islamic education curriculum is implemented in formal schools and supported by a curriculum held in Tadika (Kindergarten Education Park). Both curriculum are well implemented in meeting the needs of the Muslim community.
\end{abstract}

Keywords: curriculum, Islamic education, Muslim minority

\section{Introduction}

Educational objectives in Thailand are contained in the National Education Law of 2542 (1999) Article 6 where in managing education schools should be able to develop the perfect citizens in terms of physical, spiritual, intelligence, science, morals, cultures and customs in everyday life so that students are able to coexist with others. In article 7, the learning process should be able to instill a true awareness of politics and government in a democratic system where the King is as Head of State. Students should also be able to defend human rights, follow the constitution, respect one another, be proud as citizens of Thailand, safeguard the public interest and the State including developing cultural local product and universal science and conserve natural resources and the environment into a creative and professional individuals, and have curiosity in searching for knowledge. ${ }^{1}$

Royal government has many agendas that have been implemented in improving the quality of education, such as structuring laws of the national education system and various other legislation. Innovative programs rose as the efforts in educational reform such as BBE (Broad Base Education) or broad-based education, life skills education, education for all, competencybased curriculum, school-based management, community-based education, regional education, establishment of school boards, final school exams, national final exams and portfolio assessments

1 Translated from UU Pendidikan Nasional 2542, พระราชบัญญติการศึกษาแห่งชาติ พ.ศ. ๒๕๔๒ แก้ไขเพิ่มเติม (ฉบับที่ ๒) พ.ศ. ๒๕๕๕ และ (ฉบับที่ ๓) พ.ศ. ๒๕๕๓, มาตรา ๖ และ มาตรา ๗ 
South Thailand, precisely in the Pattani area. as a Muslim minority region, has gained attention from the Thai royal government. The total number of Thai citizens here is 64.4 million, while Muslims are $5 \%$ of that total number. For the lives of the nation and state, the Kingdom gives the widest freedom to the Thai Muslim population in performing worship and preaching. Moreover, the royal party also supports the construction of Islamic boarding schools and Islamic education institutions or Muslim schools. This is done because the royal government began to feel some setbacks experienced by some royal schools in the area of Southern Thailand.

The next step is taken based on the number of royal schools that are not developed or even dispersed because no students attended in them was that the kingdom began to make a policy to develop the curriculum of Islamic Education in the area of Southern Thailand. Thailand Prime Minister Samak Sundaravej has done it in order to take the sympathy of Muslim minority residents in southern Thailand to promote the quality of Islamic religious education in state schools. ${ }^{2}$ Suggestion proposed during the visit is the opening of cooperation of education curriculum with State of Malaysia starting from basic level to university level to fulfill the need of Islamic education in this region. this policy was also followed up by assigning the Minister of Foreign Affairs to coordinate with the Malaysian government, and undertaking the needed review to establish a primary school teaching curriculum for an improvement.

The government also discussed the determination of alumni of Islamic universities to join in teaching public schools in the southern region. The purpose of this appeal is so that the teaching of Islam in state schools can strengthen peace and security in this region. Earlier, the Prime Minister said that his government is trying to sincerely foster the spirit of mutual understanding and tolerance among Muslims and Buddhists, as the majority population in Thailand, to work together so that it can minimize the difference between the two. The Prime Minister has been making efforts to convince Muslim minorities, for example by apologizing to Muslims for the arbitrariness committed by the government in previous years and ignoring the progress of the South. The Government also appointed the first Muslim judge to resolve the case of "Yala."

The previous government required the use of Yawi language in the Islamic education system and in public schools, so the students would have nationalism and honor their king. However, in fact, teachers prefer using Malay language as a language of instruction in classrooms. This article will describe the curriculum of Islamic education in Muslim minority areas at Ban Budhee school in Pattani Province, South Thailand.

\section{Development of Islamic Education in Southern Thailand from Historical Perspective}

Muslims have a long history in the Thai Kingdom. Islam came to Pattani area, Southern Thailand approximately in the 10th or 11th centuries through trade routes. ${ }^{3}$ It is said that the presence of Islam in Pattani was initiated by the arrival of Sheikh Said, a preacher of Pasai, who succeeded in healing the severely damaged Pattani King Phaya Tu Nakpa. After that, Phaya Tu Nakpa who was a Buddhist, then converted to Islam and titled as Ismail Sultan Ismail Syah. ${ }^{4}$

Other groups of Muslims who are the majority in this country now live in the southern provinces of Pattani, Yala, Naratiwat and Satun. All of these provinces had once been the territory of Pattani Kingdom in the 12th century before the Sukhothai Kingdom was

${ }^{2}$ https://www.dakwatuna.com/2008/05/07/594/kurikulum-islam-di-sekolah-negerithailand/\#ixzz4xvTrB3DF

3 Abdurrahman, Dudung, et.al. 2002. Sejarah Peradaban Islam Dari Masa Klasik Hingga Modern. Yogyakarta: Jurusan SPI Fak Adab IAIN Sunan Kalijaga.

${ }^{4}$ Al-Azizi, Abdul Syukur. 2014. Kitab Sejarah Peradaban Islam Terlengkap. Jogjakarta: Saufa.

Volume 5, Number 1, May 2020 | 15 
established. They are from Malay race that still preserve the Malay language and culture in their daily life practices. It is mentioned in history that Pattani Kingdom is one of the most prosperous countries in Thailand, both politically and administratively. Pattani's triumph ends after being defeated by the Siamese kingdom of Bangkok. The annexation of the Thai kingdom has spawned a major problem concerning the Muslim minority in Thailand.

Due to the factor of Muslim presence in the South, the issue of ethnic Muslims appears to always be the main concern for the majority group. The long interactions and struggles of history between Muslims in the South and the Thai authorities have led to some decisions and government vigilance to agree and at the same time oppose the existence of Muslims as a group. ${ }^{5}$

Islamic education in Pattani began in $15^{\text {th }}$ century since Islam came and settled in Pattani. Basic education began in the Islamic community by studying the Qur'an. The recitation of the Qur'an is a major recitation that every member of society must pass. Qur'anic education started to become more and more popular and Islamic boarding houses started to be founded. ${ }^{6}$

Islamic boarding house education system, as found in Java (pondok pesantren) is also known to the people of Thailand. The person who first introduced this educational system was a pupil of Sunan Ampel in Java, i.e. Wan Husein. He was an influential cleric in the development of Islam in Pattani. With the introduction of the Islamic boarding system, Islamic teaching was no longer exclusively belonging to the royal elite, but also belonged to the commoners.

Islamic boarding house became the most important educational institution in Pattani. In this case, Pattani became the center of renowned Islamic religious education in Southern Thailand and the Malay peninsula at that time. Islamic boarding house became a very influential educational institution and as a place of community guidance and considered as a bulwark to defend the local culture. The students wear sarong cloth, dressed in Malay, white kopiah (male headdress) and use the Jawi writing and books. ${ }^{8}$

The process of Islamization in Pattani cannot be separated from the role of education. In the early stages, informal education was very important, such as the informal contact between preachers and the local people, followed up with the emergence of non formal education and then lastly, formal education.?

Formal education carried out by the government began at the time of the King of Chalalongkarn or Rama V in 1899. This school received less public acceptance. Seeing that, in 1921, the government passed a law requiring schools to start at the elementary school level one to four. Although the law was issued, the Islamic community in South Thailand (specifically in four areas: Pattani, Yala, Narathiwat and Satun) did not welcome the enactment of the

${ }^{5}$ Daulay, Hidar Putra.2009. Dinamika Pendidikan Islam Di Asia Tenggara.Jakarta: Rineka Cipta.
${ }^{6}$ Fauziah, Sifa. 2011. "Sejarah Perkembangan Islam di Thailand Thailand Selatan (Pattani) Pada
ke XVII Sampai SXripsi,

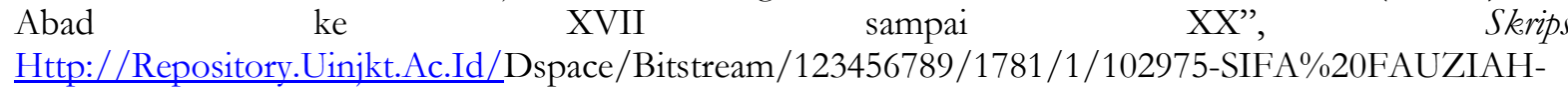

FAH.Pdf, accessed on 6 March 2017.

${ }^{7}$ Ibrahim, Malik. Februari 2012 . "Seputar Gerakan Islam di Thailand Suatu Upaya Melihat Faktor Internal dan Eksternal”. SOSIO-RELIGIA, Vol. 10, No.1, Http://Www.AifisDigilib.Org/Uploads/1/3/4/6/13465004/Revisi_No_08.__ Seputar__ Gerakan_Islam_Di_ Thailan_Pak_Malik.Pdf, accessed on 6 March 2017.

${ }^{8}$ Latifah Hanum.Januari-Juni 2013. Modernisasi Pendidikan Islam, Volume 1 No. 1. Http: //Fkip.Uisu.Ac.Id/Wp-Content/Uploads/2014/03/11_Latifah-Hanum _Modrenisasi-Pendidikan-IslamDi-Thailand-E1.Pdf, accessed on 7 May 2017.

${ }^{9}$ Syahid, Achmad et.al. Ensiklopedia Tematis Dunia Islam.Jakarta:PT Ichtiar Baru Van Hoeve.

Wahyu Illahi dan Harjani Hefni. 2012. Pengantar Sejarah Dakwah .Jakarta : Kencana Prenada Media Group.

Volume 5, Number 1, May 2020 | 16 
law. Proven statistics of 1960 , only $13.67 \%$ of the community graduated from elementary school grade one to four in the region. The community was still closely related to the Islamic education.

After 1966, the government forced every religious education institution to register itself to the kingdom under the deed "Rong Rean Son Saksana Islam" (Islamic School private education). Since then, Islamic education has changed, from the hut to the systematic and controlled madrasa. The change led to the emergence of madrasas that have the characteristics of:

1. Madrasa is a joint educational institution combining religious and formal academic education. Teachers of academic education are provided by the government. The government provides assistance to religious schools that have implemented regulations set by the government.

2. In the late 1970s, the religious schools that had these two cores (religious and academic) were welcomed by the public. Many students were sent to study science in the institution. Thus, the role of the Islamic boarding house decreased.

3. In 1981, there were a total of 199 religious schools, 122 of which undertook education and academic (general). ${ }^{10}$

In public schools, students, including Muslims, were required to study Buddhism as a compulsory course. In its development, the government allowed the teaching of Islamic knowledge in public schools, but in reality, in the eyes of Muslims, this practice fails, because the teacher was less qualified and not a permanent teacher. Meanwhile, in the future, private Islamic schools could not compete with public schools, so to balance it, the madrasas also taught secular courses so that the students could succeed in the state exam.

The graduates of religious schools were not allowed to work in government institutions. So it is not surprising that madrasas were less desirable for Muslims. For Muslim parents who sent their children to public schools, also put their children to religious schools with non-formal system at the mosque. ${ }^{11}$

\section{Islamic Education Institutions in Pattani, Southern Thailand}

1. Mosque

The existence of Mosques in Pattani not only serves as a place of worship, but also serves as an Islamic educational institution. Mosques have always played an important role in the spread of Islam in Pattani. Through these institutions, the scholars can convey the teachings of Islam to the community in the form of religious teachings on a regular basis.

In the afternoon, the mosques in Pattani remain as religious institution that are still active as a religious education institution as well even though there are already other formal education institutions. The lessons that are applied in this mosque include learning to read the Qur'an, studying the books of Jawi, learning shalawat (salutations for the Prophet Muhammad PBUH), learning to be a leader of a prayer, and perform the Friday prayer.

2. Traditional Islamic Boarding School

Islamic boarding school is an educational institution that stands as the development of the educational institutions of the palace and mosque. Islamic boarding school is the oldest educational institution in Pattani and among the oldest Islamic boarding schools are Dala, Bermin, Semela, Dual, Gersih Town and Telok Manok which have a great influence for the

10 Latifah Hanum.Januari-Juni 2013. Modernisasi Pendidikan Islam, Volume 1 No. 1. Http: //Fkip.Uisu.Ac.Id/Wp-Content/Uploads/2014/03/11_Latifah-Hanum _Modrenisasi-Pendidikan-IslamDi-Thailand-E1.Pdf, accessed on 7 May 2017.

${ }^{11}$ Daulay, Hidar Putra.2009. Dinamika Pendidikan Islam Di Asia Tenggara.Jakarta: Rineka Cipta.

Volume 5, Number 1, May 2020 | 17 
growth of Islamic education in this area, because these Islamic boarding schools had many students.

Traditional Islamic boarding school's main features:

a. Non classical, learners in South Thailand were called tok pake. They were not divided into different levels. The level of a person's knowledge is measured by the books he or she reads. Therefore, there is no year limit to end learning in these institutions.

b. The subjects in the curriculum are all focused on the study of religious studies which are only derived from the classical books.

c. Learning method focuses on the method of learning the books through reading them correctly and thoroughly and the understanding of the teacher (tok guru) and tok pake should be very well.

d. Such institution is not concerned with administrative management, such as students number, report cards, diplomas (certificates) and so forth.

3. Modern Islamic Boarding School (Private School of Islamic Education)

This institution is an educational institution resulting from the transformation process from traditional boarding school to modern boarding school. All activities are regulated by the Thai government through the Regional Education Center II, in Yala province.

The education system is implemented in the form of semi-secular dualism, namely: religious education at the level of Ibtidaiyah, Mutawasitah and 20 Tsanawiyah, while general education from middle school and high school levels.

\section{Madrasa}

The madrasa system in Thailand is an educational system that enables its students to continue their education at a higher level in overseas using their language of instruction which is in a different language than their mother tongue.

The educational system of this madrasa uses a classical system, i.e. there are levels both in the form of classes, as well as school grades. Madrasas in Thailand can be divided into three levels namely ibtidaiyah, mutawassithah, and tsanawiyah.

5. School

The education system in Thailand is guided by National Education System Law of 1999.

Based on Chapter 3, there are three forms of formal, non-formal and informal education.

a. Formal education

Consists of two levels; basic education and higher education. Basic education is conducted for 12 years consisting of 6 years of primary education, 3 years of middle school, 3 years of senior high school. Kindergarten and higher education are also included in formal education.

b. Non-formal education

Non-formal education is designated for children up to the age of 6 . It is also meant to eradicate illiteracy for people aged 14 and above.

c. Informal education

This education requires a person to learn on their own according to their interests, potentials, readiness and opportunities, such as: education in libraries and museums. Education through community learning networks for example, community learning centers, village reading centers or library, etc.

6. Islamic Higher Education

An example of Islamic higher education in Thailand is College of Islamic Studies of Princes of Songkla University. College Of Islamic Studies has the same status as faculty. This college was established in 1989 to meet the needs of the Muslim community of Thailand in 
the field of Islamic studies. This college is the only state-owned Islamic college (public college) in Thailand. It is expected to become the center of Islamic higher institution in Thailand. Besides running academic activities in the field of Islamic studies, it also conducts researches and community service. This college also often holds religious seminars and discussions on Islamic issues involving Muslim and foreign scholars. ${ }^{12}$

There are two levels of education managed by this collage. The first level is undergraduate program (4 years) which has several departments, such as Islamic law, Islamic studies, Arabic Language, Islamic Economic And Management, and Middle East Study. Second is master program that includes Islamic studies with specialization; Islamic law, Usuluddin (the pilars of Islam), History and Islamic Civilization, and Islamic Education. ${ }^{13}$

\section{Component Review in Islamic Education Curriculum}

The general view of the Islamic education curriculum is actually not much different from the curriculum. The difference lies only in the sources of the lessons. As expressed by Abdul Majid in his book Pembelajaran Agama islam Berbasis Kompetensi' (Competence-Based Islamic Learning), said that the curriculum of Islamic Education is the formulation of objectives, materials, methods and evaluation of educational derived from Islamic teachings. ${ }^{14}$

Islamic Religion Education is a conscious and planned effort in preparing learners to know, understand, live and believe in the teachings of Islam which goes with a guidance to respect people of other religions to keep the harmony among religious people to realize unity of the nation. ${ }^{15}$

According to Zakiyah Daradjat, Islamic education is an attempt to nurture learners to always be able to understand the teachings of Islam as a whole. ${ }^{16}$

The definition of curriculum in the modern view is an education program provided by the school that is not only limited to the field of study and learning activities alone, but includes everything that can affect the development and personal formation of students in accordance with the expected educational objectives so as to improve the quality of life, implemented not only at school but also outside school. The so called good curriculum must have complete and functional components. Incomplete components can lead to imperfect curriculum. ${ }^{17}$

A curriculum must have a suitability or relevance. This conformity covers two things. First, match the curriculum with the demands, needs, conditions and development of society. Second, suitability of the curriculum components, i.e. the curriculum is according to the purpose and the process is in accordance with the content and purpose. Likewise, evaluation is in accordance with the process, content and objectives of the curriculum. ${ }^{18}$

Curriculum as a system has components that are interconnected with each other, such as goals, materials, methods, media and evaluation. These components, either individually or

12 Latifah Hanum. January - June 2013. Modernisasi Pendidikan Islam, Volume 1 No. 1. Http: //Fkip.Uisu.Ac.Id/Wp-Content/Uploads/2014/03/11_Latifah-Hanum _Modrenisasi-Pendidikan-IslamDi-Thailand-E1.Pdf, accessed on 7 May 2017.

13 Ibid.

${ }^{14}$ Abdul Majid and Dian Andayani, Pendidikan Agama Islam Berbasis Kompetensi. Remaja Rosda Karya, Bandung, 2006, p. 74.

${ }^{15}$ Abdul Majid, Op., Cit. p.130.

${ }^{16}$ Ibid. p. 130.

${ }^{17}$ Lias Hasibun, Kurikulum dan Pemikiran Pendidikan, Jakarta: Gaung Persada, 2010. p. 37

18 Nana Syaodih Sukmadinata, Pengembangan Kurikulum; Teori dan Praktik. Bandung: Remaja Rosdakarya. 2010, p.102.

Volume 5, Number 1, May 2020 | 19 
collectively, become the main basis in developing the learning system. There are several opinions that confirm the curriculum component. Ralph W. Tyler states that there are four components of the curriculum which are goals, materials, organization and evaluation. In line with that opinion, Hilda Taba writes that the components of the curriculum include objectives, subject matter, methods and organization and evaluation. The components of the curriculum are interconnected. Each component is closely related to the other components. The purpose is to determine what materials are studied, how the learning process will be like and what should be assessed. Similarly, the assessment may affect other components. ${ }^{19}$

Tohari Musnamar has identified and detailed the components considered in the framework of curriculum development; basic and educational goals, educators, educational materials, gap systems, delivery systems, evaluation systems, students, the process of learning, follow-up, curriculum, guidance and counseling, education administration, facilities and infrastructure, development effort, education cost and environment. Meanwhile, Hasan Langgulung divided the curriculum into four elements: educational objectives, educational content, teaching methods and assessment methods.

Principle components of curriculum consist of: objectives, materials, methods and evaluation. ${ }^{20}$

\section{Objective}

Objective is the targeted curriculum component that must be achieved from implementing a curriculum. This component is very important, because through the objectives, process and evaluation materials can be controlled in order to achieve the objectives of the curriculum. The objectives of the curriculum can be specified into the general learning objectives which is the objectives that should be achieved in one semester. While the specific learning objectives are targeted in each meeting. In the context of competency-based curriculum, the general learning objectives are called by the term competency standards and specific learning objectives are called basic competence.

\section{Content/Material}

Material is a component designed to achieve the objectives. What is meant by material is the study materials consisting of knowledge, values, experiences and skills developed into the learning process to achieve the objectives.

Students learn in the form of interaction with their environment, other people's environment, tools and ideas. A teacher's main job is to create such environment, to encourage students to engage in productive interactions and to provide them with the design in a teaching plan. Learning materials are arranged logically and systematically, in the form of ${ }^{21}$ :

a. Theory; a set of interrelated constructs or concepts, definitions or prepositions, presenting a systematic view of the phenomena by specifying the relationships among the variables with the intent of explaining and predicting the phenomenon.

b. Concepts; an abstraction formed by the organization of specifications, a short definition of a group of facts or symptoms.

c. Generalization; general conclusions based on specific matters, derived from analysis, opinion or verification in research.

d. Principle; main idea, the scheme pattern that exists in the material that develops the relationship of several concepts.

${ }^{19}$ Muhammad Zaini, Pengembangan Kurikulum; Konsep Implementasi, Evaluasi dan Inovasi. Yogyakarta: Teras. 2009, p. 79-81

${ }^{20}$ Lias Hasibuan, Kurukulum dan Pemikiran Pendidikan. p. 38-40

${ }^{21}$ Nana Syaodih Sukmadinata, Pengembangan Kurikulum Teori dan praktek, p. 105 
e. Procedure; a series of sequential steps in the subject matter to be done by students.

f. Fact; a number of specific information on the material which is considered important, consisting of terminology, persons and places and events.

g. Terms, new vocabulary introduced in the material.

h. Example illustration; things or actions or processes that aim to clarify a description or opinion.

i. Definition; explanation of the meaning or understanding of a thing/word in general.

j. Prepositions; the means used to deliver the subject matter in an effort to achieve the curriculum objectives.

The contents of the curriculum is everything that is given to the students in teaching and learning activities in order to achieve the objectives. The contents of the curriculum include the types of subject areas taught and the content of each field of study. Fields of study are adjusted to the existing type of education, level of education and educational path. The criteria that can assist the design of curriculum in determining the contents of the curriculum include:

a. The contents of the curriculum should be suitable, appropriate and meaningful for student development.

b. The contents of the curriculum should reflect social reality.

c. The contents of the curriculum must contain test-resistant scientific knowledge.

d. The content of the curriculum should contain clear learning materials.

e. The contents of the curriculum can support the achievement of educational goals.

3. Method

Strategies and methods are the third component in curriculum development. This component has a very important role, because it deals with the implementation of the curriculum. The strategy refers to the approaches and methods and teaching tools used in teaching. But in essence, the teaching strategy is not limited there. Teaching strategy talks are illustrated by the way in which the execution of the teaching, conducting assessment, guidance and organizing activities, both general and specific in teaching.

The curriculum implementation strategy deals with how the curriculum is implemented at school. Curriculum is a plan, ideas and expectations which must be realized in real schools, so as to be able to lead students to achieve the objectives of education. A good curriculum will achieve maximum results if the implementation produces something good for the students. The components of the curriculum implementation strategy include teaching, assessment, guidance and counseling and arrangement of school activities. ${ }^{22}$

Strategy includes plans, methods and tools of activities planned to achieve certain objectives. Learning strategy is an action plan (sequence of activities) including the use of methods and the utilization of various resources/strengths in learning. Efforts to implement the plan that has been prepared in the real activity for the objectives that have been prepared to be achieved optimally is called the method.

It has been mentioned above that seen from the philosophy and theory of education underlying the development of curriculum, there are differences in determining objectives and learning materials. This of course has consequences also on the determination of learning strategies that will be developed. If the goal in learning is intellectual-information mastery, as many developed by classical philosophers in the framework of cultural inheritance or perpetuity, the learning strategy developed will be more teachercentered. Teachers are central figures in the learning process and are seen as centers of

${ }^{22}$ Hamid Syarif. Pengembanagan Kurikulum, Pasuruan: Garoeda Buana Indah, 2009, p. 108

Volume 5, Number 1, May 2020 | 21 
information and knowledge. While learners are only considered as objects that passively receive information from the teacher. Learning methods and techniques used in general are mass presentation (expository), such as lectures or seminars. In addition, learning tends to be more textual.

The teacher-oriented learning strategy got some reaction from the progressive group. According to the progressivism, the one who should be active in a learning process is the learner itself. Learners actively determine the material and learning objectives in accordance with their interests and needs, as well as determine how the most appropriate way to obtain material and achieve learning objectives. Student-centered learning has the support of reconstructivists who emphasize the importance of learning through group dynamics.

Learning tends to be contextual, the methods and learning techniques used are no longer in the form of presentation from the teacher but rather individual, direct, and utilize group dynamics (cooperative) processes, such as modular learning, observation, simulation or role playing, discussions and the like. Furthermore, with the emergence of technologybased learning that emphasizes the importance of competency control brings its own implications in the determination of learning strategies. Although still a mastery of material or competence as in the classical approach, but in technological learning is still possible for learners to learn individually.

In technological learning, it is possible for learners to learn without meeting face-toface with the teacher, such as through the internet or other electronic media. The role of teachers in technological learning is more likely to be the director of a learning process, which seeks to direct and organize students to perform learning actions in accordance with what has been previously designed. Based on the above description, there are many possibilities for determining learning strategies and each learning strategy has its own weaknesses and advantages.

\section{Evaluation}

The evaluation component is a comparable component of the curriculum like a goalie in a soccer game, the functioning of the evaluation means selecting who is eligible to graduate and who is not. Therefore, the students who can reach the target are eligible to graduate, while the students who cannot reach the target (the expected behavior) are not eligible for graduation. Judging from the function and urgency of evaluation, from the evaluation component, for example, how many teachers who teach a subject that is in accordance with the teacher's educational background and also supported by the available media and learning tools and normal students. ${ }^{23}$

The evaluation component is very important for the implementation of the curriculum. The results of an evaluation can give clues as to whether the target that you wanted to reach has been achieved or not. In addition, evaluation is also useful for assessing whether the curriculum process is running optimally or not. Thus, directions on the implementation of the curriculum can be obtained. Based on those directions, improvements can be done. Curriculum evaluation should be done continuously. It is necessary to clearly establish what will be evaluated using clear benchmarks. In connection with the design of this curriculum, evaluation is done to achieve two main objectives, namely; first, evaluation of curriculum products or outcomes; second, evaluation of the curriculum process. ${ }^{24}$

${ }^{23}$ Oemar amalik, Kurikulum Pembelajaran, Jakarta: Bumi Aksara, 2008, p. 28

${ }^{24}$ Muhammad Ali, Pengembangan Kurikulum di Sekolah, Bandung: Sinar Baru Algensindo, 2008, p. 60

Volume 5, Number 1, May 2020 | 22 
Curriculum evaluation is intended to assess a curriculum as an educational program for determining the efficiency, effectiveness, relevance and productivity of the program in achieving educational goals. Efficiency accounts for the use of time, energy, infrastructure and other resources optimally. Effectiveness is related to the selection or use of the main or the most appropriate way in achieving a goal. Relevance is regarded with the suitability of a program and its implementation with the demands, needs and interests of the community and students. Optimal productivity is related to the results achieved from the program. ${ }^{25}$

\section{The Profile of Ban Budhee School}

Ban Budhee School is geographically located at the tip of Datuk Island. Budhee village is a famous coastal communities. Ban Budhee School is the largest school in the district Laem Pho of Pattani province South Thailand from two other schools such as Datuk school and Teluk Sembilan school. Islamic-based school empire has expanded rapidly way faster than other royal schools and non-Islamic-based. The school consists of kindergarten, elementary school and middle school. The release of middle school operating license in Budhee school is because this school has met the requirements as a large school whose students have reached a thousand people.

The vision of Ban Budhee School is to become an institution that can build a modest Islamic life with science and technology as their assets. Their missions are: (1) to establish an atmosphere of Muslim life, (2) to teach simple life, (3) to emphasize work ethics, (4) to collaborate with the community, and (5) to provide knowledge, science and technology.

The entry of the curriculum and Islamic religious education in Ban Budhee is still relatively new. The approval of the submission of Budhee into an Islamic school is the result of the efforts of the people in the neighborhood who desperately need Islamic education in their area. Because the Budhee area has been inhabited by Malay Islamic community, back then, the children at the village had to go to school which had Islamic material located far outside of the village. Because at that time, the closest school in the district of Laem Pho was not Islamicbased. Therefore, to meet the needs of the local community and the development of education in the area of this end of the island, the kingdom and the government approved the implementation of Islamic education curriculum in Ban Budhee school.

\section{Islamic Education Curriculum in Ban Budhee School}

As a Muslim minority country, the kingdom has made the renewal of Islamic education. Although initially the subjects of Islamic education in did not exist in public schools, the kingdom has launched Islamic education in schools in the last ten years. The subject previously only included one meeting a week of religious education, now 8 Islamic educational materials and 8 matter of general knowledge are applied. The Islamic educational material consists of: Arabic, Malay, creed, morality, Quran, hadith (the sayings of the Prophet PBUH), and Islamic jurisprudence and history. General knowledge materials include: English, Thai, science, social science, mathematics, physical education, soft-skills and art. The schools run for 5 days and 7 hours per day, so students study for 35 hours a week. Islamic education subjects are integrated with each other. For example, the Arabic material is related with the material of jurisprudence,

\footnotetext{
${ }^{25}$ Nana Sudjana, Pembinaan dan Pengembangan Kurikulum di Sekolah, Bandung: Sinar Baru Algensindo, 2005, p. 49
}

Volume 5, Number 1, May 2020 | 23 
theology, morality, Quran and hadith because the materials are written in Arabic since many references are from the Quran and badith..

The curriculum in the country of Thailand used bottom up approach, starting with gathering Islamic education teachers from the best schools in South Thailand to develop the curriculum. The results of a curriculum that has been prepared and then given to the kingdom to be approved and enforced in the entire country of Thailand. In fact, the curriculum that has been already established by the kingdom can not meet the need of the students. So, every teacher also provides additional materials to support the existing curriculum.

Although the royal government gives legitimacy to the implementation of the curriculum, it is still problematic. The people think that the royals merely fulfill the right to the enforcement of Islamic education curriculum without updating the curriculum for seven years. According to Islamic education teachers, this absence of updates makes the learning curriculum flat or boring and has less value. Then, the teachers are trying to give a spirit to the curriculum with passion, hard work, and tolerance. (Interview)

Additional curriculum materials from the school policy is 30 minutes before the end of the learning activities. The teachers of Islamic education add extracurricular activities that include tarbiyah rubiyah (spiritual education), morals, hadith, mubadatsah (conversations) and khitobah (speech). Materials presented at that session are under the authority of teachers in each classroom. In addition, in shaping up the morals of the students, the school holds drug prevention assembly.

Specific policies in state schools in Thailand are divided into three, namely; large schools have 1000 students or more, medium schools have 500 students or more and tsmall schools have 200 students or more. Ban Budhee School is located in Budhee village of Laem Pho sub-district, Pattani Province, South Thailand, and this school belongs to the large school. The school has 1020 students with 60 teachers that includes kindergarten, elementary and junior high students. The permit of the establishment of junior high school level is also due to the category of the school that has reached large school with a number of students over 1000 .

In terms educators or teachers, teacher of Islamic education is an appointed teacher of the kingdom and they must at least hold a bachelor degree. If the teacher has had religious studies background but did not obtain education course, $\mathrm{s} /$ he is required to take a diploma for 3 semesters of education courses. Only then, s/he can become a teacher after graduating from the diploma course and has obtained a teaching license. Most of the Islamic education teachers are graduates from universities abroad, especially from Middle Eastern countries (Jordan, Saudi Arabia, Egypt, Yemen, etc.) and neighboring countries such as Malaysia and Indonesia.

In terms of process, the learning is carried out by various methods, such as lectures, drill, and private recitation with integrated LCD. At the beginning of language learning in the field of study, students must come forward one by one for memorizing the material assigned by the teacher. Education in Islamic religious education is also supported by a special room of Islamic education or commonly called religious laboratory. This lab is enabled to support the effectiveness of learning Islamic teachings.

This study does not look at the curriculum narrowly and does not define curriculum only limited to the collection of subjects or teaching materials but it is interpreted broadly, that the curriculum covers all the experience that the students gain for direction, guidance and responsibility of the school. The curriculum is also defined as a written document of a plan or program of education, as well as the implementation of the teaching plan. The curriculum can include a very broad scope, i.e. as a teaching program at any level of education, and may also involve narrow scope, such as a teaching program of a subject. Great quotes hanging on the walls 
are also evidence that the school is trying to plant moral values to the students. There are also images of children saluting in each classroom door. It becomes part of the curriculum as a form of education and moral ethics that is applied to students in order to have a respectful attitude, politeness, and courtesy to others.

In terms of evaluation, the evaluation of Islamic religious education program conducted through the stages of daily, weekly, mid-term and end of the semester evaluations. As for the national evaluation, it is conducted through a national test to material which is called ONET for general knowledge, and INET for Islamic education materials. The preparation of the national test is organized by the royal government by inviting experts in education. Since the evaluation process is centrally focused, the assessment of student learning outcomes have applied the same standards nationally.

\section{Conclusion}

From the explanation of the paper, it can be concluded that the application of Islamic education curriculum in the Ban Budhee School have met the following components: (1) objective, (2) material, (3) method, and (4) evaluation. Objectives can be adjusted between the education objectives set forth by the Law and the vision and missions formulated by Ban Budhee School. On the material component, Islamic religious education subjects cover 8 materials, such as Arabic, Malay, creed, morality, Quran, badith, Islamic jurisprudence and the history of Islam that have been prepared well because all materials are compiled in a handbook. Only the renewal of teaching materials that has not been performed continuously. Curriculum development is still considered slow so that teachers are required to be creative in developing content to be studied. For the methods used by teachers are still on the extent of lectures, drill and memorization. Planting moral values can be done by hanging quotes on the walls and images of students giving salutation on each classroom door. The last component, program evaluation, is carried out in stages starting from daily, weekly, mid-term to end of the semester evaluations. Although, as a Muslim minority country, the national evaluation in Islamic religious education is also organized nationally through INET. On the other hand, the application of Islamic education curriculum is also supported by the Islamic education curriculum in Tadika Islamic educational materials which teaches 8 Islamic subjects that are the same as mentioned before. With that, the needs of the Muslim community as a minority towards Islamic religious education for the younger generation can already be met.

\section{References}

Abdul Majid, dan Dian Andayani, Pendidikan Agama Islam Berbasis Kompetensi. Remaja Rosda Karya, Bandung, 2006.

Abdurrahman, Dudung, et.al.2002. Sejarah Peradaban Islam Dari Masa Klasik Hingga Modern.Yogyakarta:Jurusan SPI Fak Adab IAIN Sunan Kalijaga.

Al-Azizi, Abdul Syukur.2014.Kitab Sejarah Peradaban Islam Terlengkap. Jogjakarta :Saufa.

Daulay, Hidar Putra.2009. Dinamika Pendidikan Islam Di Asia Tenggara.Jakarta: Rineka Cipta.

Fauziah, Sifa. 2011. "Sejarah Perkembangan Islam di Thailand Thailand Selatan (Pattani) Pada Abad ke XVII sampai XX”, Skripsi, Http://Repository.Uinjkt.Ac.Id/Dspace/Bitstream/123456789/1781/1/102975-

SIFA\%20FAUZIAH-FAH.Pdf, diakses tanggal 6 Maret 2017.

Hamid Syarif. Pengembanagan Kurikulum, Pasuruan: Garoeda Buana Indah, 2009 
https://www.dakwatuna.com/2008/05/07/594/kurikulum-islam-di-sekolah-negerithailand/\#ixzz4xvTrB3DF

Ibrahim, Malik. Februari 2012 . "Seputar Gerakan Islam di Thailand Suatu Upaya Melihat Faktor Internal dan Eksternal". SOSIO-RELIGIA, Vol. 10, No.1, Http://Www.AifisDigilib.Org/Uploads/1/3/4/6/13465004/Revisi_No_08.

Gerakan_Islam_Di_Thailan_Pak_Malik.Pdf, diakses tanggal 6 Maret 2017

Seputar_

Latifah Hanum.Januari-Juni 2013. Modernisasi Pendidikan Islam, Volume 1 No. 1. Http: //Fkip.Uisu.Ac.Id/Wp-Content/Uploads/2014/03/11_Latifah-Hanum _ModrenisasiPendidikan-Islam-Di-Thailand-E1.Pdf.diakses tanggal 7 Mei 2017.

Lias Hasibun, Kurikulum dan Pemikiran Pendidikan, Jakarta: Gaung Persada, 2010.

Muhammad Ali, Pengembangan Kurikulum di Sekolah, Bandung: Sinar Baru Algensindo, 2008.

Muhammad Zaini, Pengembangan Kurikulum; Konsep Implementasi, Evaluasi dan Inovasi. Yogyakarta: Teras. 2009.

Nana Sudjana, Pembinaan dan Pengembangan Kurikulum di Sekolah, Bandung: Sinar Baru Algensindo, 2005

Nana Syaodih Sukmadinata, Pengembangan Kurikulum; Teori dan Praktik. Bandung: Remaja Rosdakarya. 2010.

Oemar amalik, Kurikulum Pembelajaran, Jakarta: Bumi Aksara, 2008

Syahid, Achmad et.al. Ensiklopedia Tematis Dunia Islam.Jakarta:PT Ichtiar Baru Van Hoeve.

UU Pendidikan Nasional 2542, พระราชบัญญติการศึกษาแห่งชาติ พ.ศ. ๒๕๔๒ แก้ไขเพิ่มเติม (ฉบับที่ ๒) พ.ศ. ๒๕๔๕ และ (ฉบับที่ ๓) พ.ศ. ๒๕๕๓, มาตรา ๖ และ มาตรา ๓

Wahyu Illahi dan Harjani Hefni. 2012. Pengantar Sejarah Dakwah .Jakarta : Kencana Prenada Media Group. 